\title{
Triazole- and Thiadiazolecontaining Macroheterocycles: Review of Main Achievements for Last Decade
}

\author{
Yu. V. Suvorova, ${ }^{a}$ T. V. Kustova, ${ }^{a}$ E. A. Danilova, ${ }^{a}$ and M. N. Mileeva ${ }^{\mathrm{b}}$ \\ avanovo State University of Chemistry and Technology, 153000 Ivanovo, Russia \\ ${ }^{\mathrm{b}}$ Ivanovo State Medical Academy, 153012 Ivanovo, Russia \\ ${ }^{\circledR}$ Corresponding authorE-mail: butina@isuct.ru
}

\begin{abstract}
The work reviews main achievements of last decade in the field of synthesis and properties research of macroheterocyclic compounds of ABBB-and AABAAB-types, A being 1,2,4-triazole, 1,2,4-or 1,3,4-thiadiazole moiety, and B being (un) substituted isoindoline resudie. All the compounds were obtained through interactions between heterocyclic diamine and 1,3-diiminoisoindoline or phthalonitrile under different conditions. The ABBB-type target products have properties of "molecular chameleons"; in other words, they possess an unique ability to postsynthetically modify the molecular optic properties. The AABAAB-type products as macroheterocyclic compounds with an expanded coordination cavity allow to insert one large and several smaller metal atoms into an intramolecular cavity. Therefore, the compounds become potential anion receptors. Moreover, a bathochromic shift of maximum absorption band into infra-red region of electron spectra of AABAAB macroheterocycles with expanded conjugated $\pi$-electron system can promote their use as photodynamic therapeutic agents.
\end{abstract}

Keywords: Diaminotriazole, diaminothiadiazole, macroheterocyclic compound, expanded coordination cavity.

\section{Триазол- и тиадиазолсодержащие макрогетероциклы: обзор основных Аостижений за последние десять лет}

\author{
Ю. В. Суворова, ${ }^{a}$ Т. В. Кустова, ${ }^{a}$ Е. А. Аанилова, ${ }^{a}$ М. Н. Милеева ${ }^{\mathrm{b}}$ \\ авановский государственный химико-технологический университет, 153000 Иваново, Россия \\ ${ }^{\mathrm{b}}$ Ивановская государственная медицинская академия, 153012 Иваново, Россия \\ @E-mail: butina@isuct.ru
}

\begin{abstract}
Данная работа представляет собой обзор достижений за последнее десятилетие в области синтеза и исследования свойств макрогетероииклических соединений $A B B B-и$ А 1,2,4-триазола, 1,2,4- или 1,3,4-тиадиазола, B-остаток (не)замещзенного дииминоизоиндолина. Все соединения были получены взаимодействием соответствующчего гетерочиклического диамина и 1,3-дииминоизоиндолина или фталонитрила при различных условиях. Целевые продукть АВВВ-типа обладают свойствами «молекулярных хамелеонов», т.е. уникальной возможностью постсинтетической модификации оптических свойств молекуль. Продукты ААВААВ-типа - это макрогетероциклические соединения с увеличенной координационной полостью, которая позволяет ввести один атом металла большого радиуса или несколько атомов металла малого радиуса, поэтому эти соединения потенциально могут быть использованы в качестве анионных рецепторов. Кроме того, батохромный сдвиг максимума полосы поглощения в ближнюю ИК область электронных спектров макрогетерочиклов ААВААВ-типа, имеющих увеличенную л-электронную систему сопряжения, может способствовать их использованию в качестве терапевтических агентов в фотодинамической терапии.
\end{abstract}

Ключевые слова: Диаминотриазол, диаминотиадиазол, макрогетероциклическое соединение, расширенная координационная полость. 


\section{Introduction}

Macroheterocyclic compounds (Mcs) are analogues of porphyrins and phthalocyanines, where one or several isoindole fragments are substituted by heterocyclic residues. The first macroheterocycles containing four alternating isoindole and pyridine units linked by azabridges were synthesized in 1952 year by Elvidge, Linstead ${ }^{[1]}$ and, independently of them, by Campbel. ${ }^{[2]}$

The poor solubility of unsubstituted Mcs prevents their wide application making chemists to involve various substituents both to isoindole and to heterocycle moieties.

A great variety of Mcs having been obtained nowadays, it is possible to classify them according to the type and number of heterocyclic fragments. It is usually supposed that $\mathrm{A}$ is a heterocyclic diamine residue, B being an isoindole unit. In 1996 a method of regioselective synthesis of symmetrical ABAB-type Mc, employing 1-dodecyl-3,5-diamino-1,2,4triazole moieties with nonlinear optical properties, was proposed. ${ }^{[3]}$ Danilova et al. ${ }^{[4]}$ synthesized ABAB Mcs containing two 3,5-diamino-1,2,4-thiadiazole fragments and two different substituted isoindole residues. In 2001 single asymmetrical ABBB-type Mc with unsubstituted 1,3,4-thiadiazole unit was produced. ${ }^{[5]}$ In 2002 Islyaikin et al.$^{[6]}$ obtained ABBB-type Mc embracing one 1-dodecyl-substituted triazole and three 3,4-di(4-tert-butylphenyl)-2,5-diimipirroline cycles with acid-base properties. ABBB Mcs consisting of $3 N$-alkylated 5-amino-2-imino-1,3,4-thiadiazoline moieties demonstrated strong fluorescence in UV region spectra. ${ }^{[4]}$

Macroheterocycles with more than four heterocyclic fragments are known as Mcs with an expanded coordination cavity. These compounds are of a particular interest due to their ability to be used as therapeutic agents in photodynamic therapy and virology, ${ }^{[7]}$ anion receptor ${ }^{[8]}$ and nonlinear optic devices. ${ }^{[9]}$ There are various types of Mcs with an expanded coordination cavity such as ABA$\mathrm{BAB}, \mathrm{ABBABB}$ and $\mathrm{AABAAB}$ described in the literature, ABABAB Mcs having been most studied.

The discovery history of ABABAB Mc is sufficiently interesting. In 1971 and 1990 macroheterocyclic compound embracing 1,3,4-thiadiazole residues was described as ABAB Mc. ${ }^{[10-13]}$ The structure of this Mc was studied by secondary-ion mass spectrometry, ${ }^{1} \mathrm{H},{ }^{13} \mathrm{C}$ NMR spectroscopy, quantum chemistry calculation in $2001 ;^{[5,14]}$ by gas electron diffraction in $2008^{[15]}$ and by X-ray analysis in 2010. ${ }^{[16]}$ All these methods allowed establishing ABABAB-type of this Mc. The specific structure of ABABAB Mc is thiadiazole ring inversion by sulfur atoms outwards intracyclic cavity. This preferred conformation is due to large size of the sulfur atom and the existence of intramolecular hydrogen bonds between hydrogen atom isoindole ring and lone electron pairs of nitrogen atoms thiadiazole ring. ${ }^{[5]}$ The intramolecular cavity of ABABAB Mc can accept three transition metal ions such as $\mathrm{Ni}^{2+}, \mathrm{Cu}^{2+}, \mathrm{Co}^{2+}$ or one large-radius ion, for example, $\mathrm{La}^{3+},{ }^{[17]}$ this phenomenon becoming attractive to being applied in magnetic resonance imaging region. ${ }^{[16]}$

In 2001 a researcher group ${ }^{[18]}$ has synthesized several expanded ABBABB analogues by two methods: 1) the dimerization of the corresponding three-unit intermediates in 2-ethoxyethanol at reflux temperature; 2) the condensation of a suitable 1,3-diiminoisoindolenine with 3,5-diamino-1,2,4-triazole at stoichiometric ratio in the presence of the appropriate metal acetate in acetonitrile at $70^{\circ} \mathrm{C}$. The researchers have demonstrated that the yield of the target compound was much larger in the former method owing to the mixture of expanded Mc and phthalocyanine formed at one-step method.

AABAAB Mcs containing diiminoisoindoline and diphenyl ester ${ }^{[19]}$ or bis(5-amino-1,3,4,-thiadiazole-2) disulfide $^{[20]}$ moieties were also studied. The latter can be used for selective purification of aqueous solutions of heavy metal ions like strontium and lead due to coordination bonds between the metal cation and intracyclic nitrogen atom. ${ }^{[21]}$

Our research group obtained different $\mathrm{ABBB}$ and $\mathrm{AABAAB}$ Mcs in the last several years, their discussing being the purpose of the review.

\section{ABBB-type Mcs with Various Heterocyclic Fragments}

Several ABBB macroheterocyclic compounds with alkyl substituted 1,2,4-triazoles, 1,3,4- and 1,2,4-thiadiazoles were obtained. All these compounds produced by various methods have different properties due to their geometric characteristics. ${ }^{[22,23]}$ Our research group have synthesized Mcs 5-8 consisting of $3 N$-alkylated 1,3,4-thiadiazole cycle by the interaction of corresponding 3-alkyl-5-amino-2-imino-1,3,4thiadiazoines 1-4 with 1,1-dimethoxy-3-iminoisoindoline at the $1: 3$ ratio in boiling methanol (Scheme 1). ${ }^{[24]}$

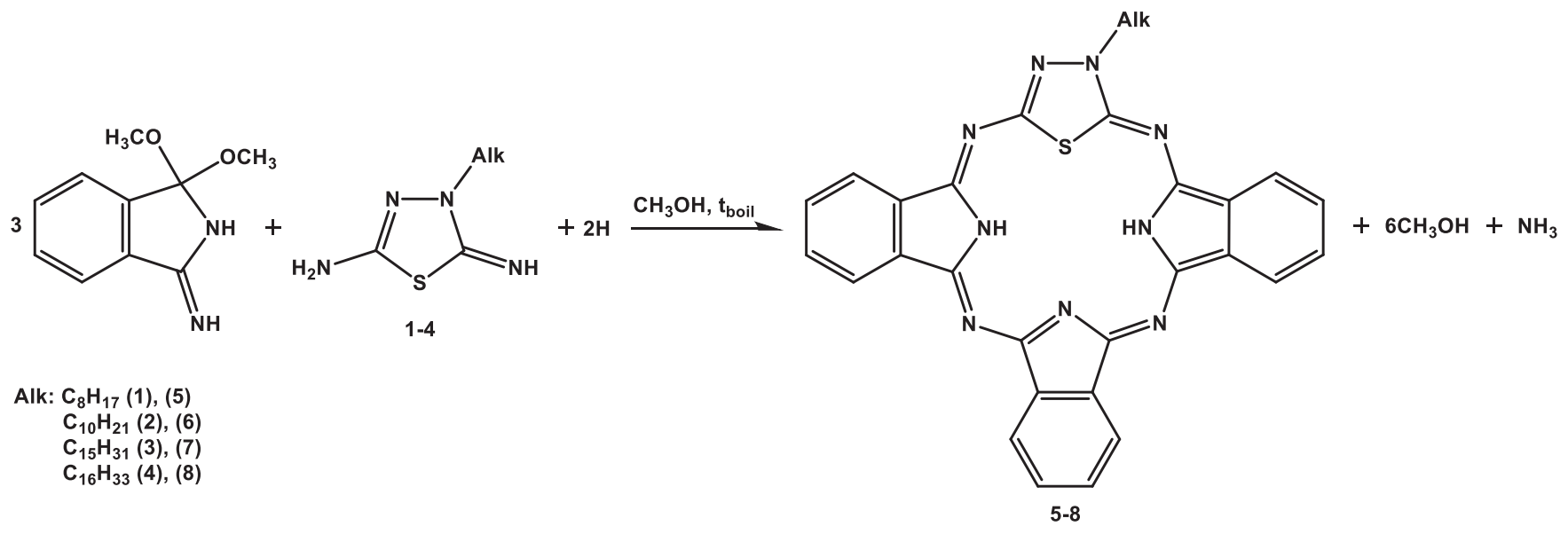


The stoichiometry of the reactions of 1,1-dimethoxy3 -iminoisoindoline or 1,3-diiminoisoindoline with $\mathrm{N}$-alkylthiadiazolines is observed only in the presence of a source of proton in the left-hand side of the reaction equation. The question on the nature of the proton donor was discussed by Elvidge and Linstead as early as in 1955, when they studied the reaction of phthalocyanine obtaining. ${ }^{[25]}$ Reductive systems are reported to comprise aliphatic alcohols and sodium alcoholates. ${ }^{[26,27]}$ Therefore, we suggested that it was such a system that was formed during alkoxyiminoindolenine synthesis. ${ }^{[24]}$

We demonstrated that microwave radiation (MWR) ${ }^{[28]}$ widely utilized in industry, science, medicine, engineering and life is possible to use in the synthesis of ABBB-type Mc. Applying MWR allowed significantly decreasing the reaction time and increasing the target product yield (almost twice). The reaction was carried out by the condensation of corresponding substituted phthalonitriles 9, 10 with alkyltriazoles 11, 12 (Scheme 2) without solvents during $20 \mathrm{~min}$ at MWR (dynamic power not more than 100 W) using a laboratory system of the focused microwave radiation «Discovery Labmate» («CEM Corp.»). The synthesis of triazole-containing Mcs is usually performed step by step through obtaining BAB product. Accordingly, BAB compounds 13-15 were formed by interaction of $2 \mathrm{~mol}$ of phthalonitrile $\mathbf{9}$ or $\mathbf{1 0}$ with $1 \mathrm{~mol}$ of alkyltriazole $\mathbf{1 1}$ or 12 at the first stage, at the second stage BAB products being transformed into target ABBB Mcs 16-18.

We managed to synthesize ABBB-type Mcs 24-28 on basis of $2 N$-butyl-, $2 N$-heptyl-, $2 N$-octyl-, $2 N$-nonyl-, $2 \mathrm{~N}$-dodecyl-5-amino-3-imino-1,2,4-thiadiazolines by the con- densation of corresponding $2 N$-alkylthiadiazoline 19-23 with 1,3-diiminoisoindoline in media of phenol at $100-110{ }^{\circ} \mathrm{C}$ for more than 50 hours (Scheme 3). ${ }^{[29]}$ Though the yield of the Mcs obtained was low because of the difficulty of their purification they had very interesting properties of molecular chameleons, ${ }^{[30]}$ which is an unique ability for postsynthetic modification of the molecular optic properties. ${ }^{[31]}$

The UV-Vis spectra of compounds 5-8, 16-18, 24-28 were similar to each other. ${ }^{[24,28,31]}$ There were two absorption bands at 263-283 nm and at 473-532 nm. The first band $(263-283 \mathrm{~nm})$ indicates the presence of the heterocyclic fragment. The initial heterocyclic compound nature affects not only the synthesis procedure but also the features of the target product structure. 1,2,4-Thiadiazole-containing Mcs (24-28) had no protons in an intracyclic cavity unlike 1,2,4-triazole (16-18) and 1,3,4-thiadiazole (5-8) ABBB Mcs. This fact was confirmed by ${ }^{1} \mathrm{H}$ NMR data. Signals in the 11.5-12.5 ppm region of ${ }^{1} \mathrm{H}$ NMR spectra of 1,2,4-triazole- $(\mathbf{1 6}-\mathbf{1 8})^{[28]}$ and 1,3,4-thiadiazole-containing (5-8) ${ }^{[24]}$ Mcs corresponded to the resonance of protons at intracyclic nitrogen atom of isoindole moieties. In ${ }^{1} \mathrm{H}$ NMR spectra of 1,2,4-thiadiazole-containing Mcs (24-28) ${ }^{[31]}$ the similar signals are not observed. Mcs (24-28) were revealed to be protonated both at the absence of protons and the presence of nitrogen atoms in the intracyclic cavity. The phenomenon was studied by us both experimentally in two systems: $\mathrm{CH}_{2} \mathrm{Cl}_{2}-\mathrm{CF}_{3} \mathrm{COOH}$ and $\mathrm{C}_{2} \mathrm{H}_{5} \mathrm{OH}-\mathrm{H}_{2} \mathrm{SO}_{4}$ and theoretically by DFT method with B3LYP hybrid functional and the $6-31 \mathrm{G}(\mathrm{d}, \mathrm{p})$ basic set. ${ }^{[31]}$ According to spectrophotometric titration, one acid molecule participated in protonation at the first stage. Quantum chemistry calculation demonstrated that the most energetically favor-<smiles>[R]Oc1cc(C#N)c(C#N)cc1[N+](=O)[O-]</smiles>

9,10<smiles>CC(C)C1(C)CCCCC1</smiles>

11,12

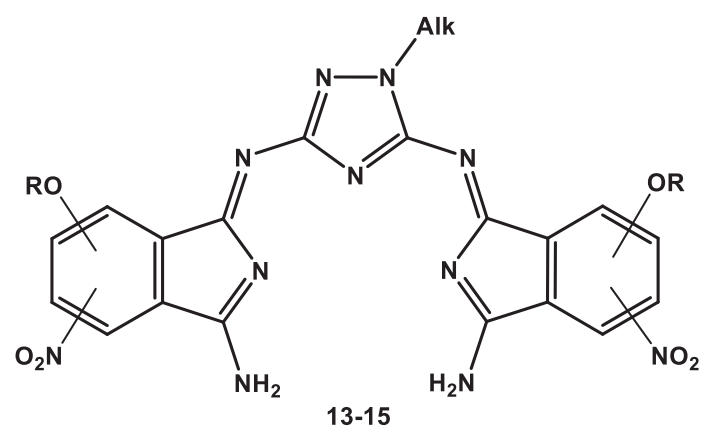

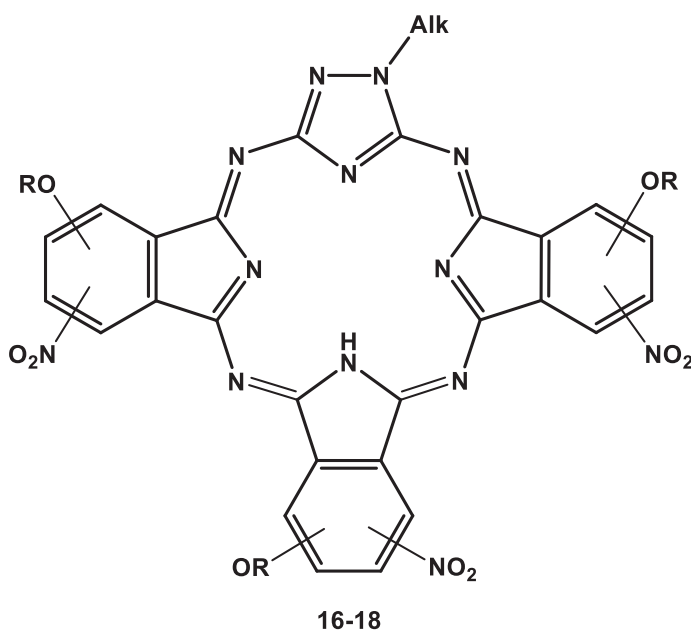
ii

R: 4- $\left(\mathrm{Ph}_{3} \mathrm{C}\right) \mathrm{C}_{6} \mathrm{H}_{4}(9)$ 4-t- $-\mathrm{ButC}_{6} \mathrm{H}_{4}(10)$ Alk: $\mathrm{C}_{10} \mathrm{H}_{21}$ (11) $\mathrm{C}_{16} \mathrm{H}_{33}(12)$ R: 4- $\left(\mathrm{Ph}_{3} \mathrm{C}\right) \mathrm{C}_{6} \mathrm{H}_{4}$ Alk: $\mathrm{C}_{10} \mathrm{H}_{21}$ (13), (16)

R: 4-t-Butc ${ }_{6} \mathrm{H}_{4}$ Alk: $\mathrm{C}_{16} \mathrm{H}_{33}$ (14), (17) R: 4- $\left(\mathrm{Ph}_{3} \mathrm{C}\right) \mathrm{C}_{6} \mathrm{H}_{4}$, Alk: $\mathrm{C}_{16} \mathrm{H}_{33}$ (15), (18)

i: $\mathrm{MWR}, 120^{\circ} \mathrm{C}, 10 \mathrm{~min}$ ii: MWR, $150^{\circ} \mathrm{C}, 10 \mathrm{~min}$ 


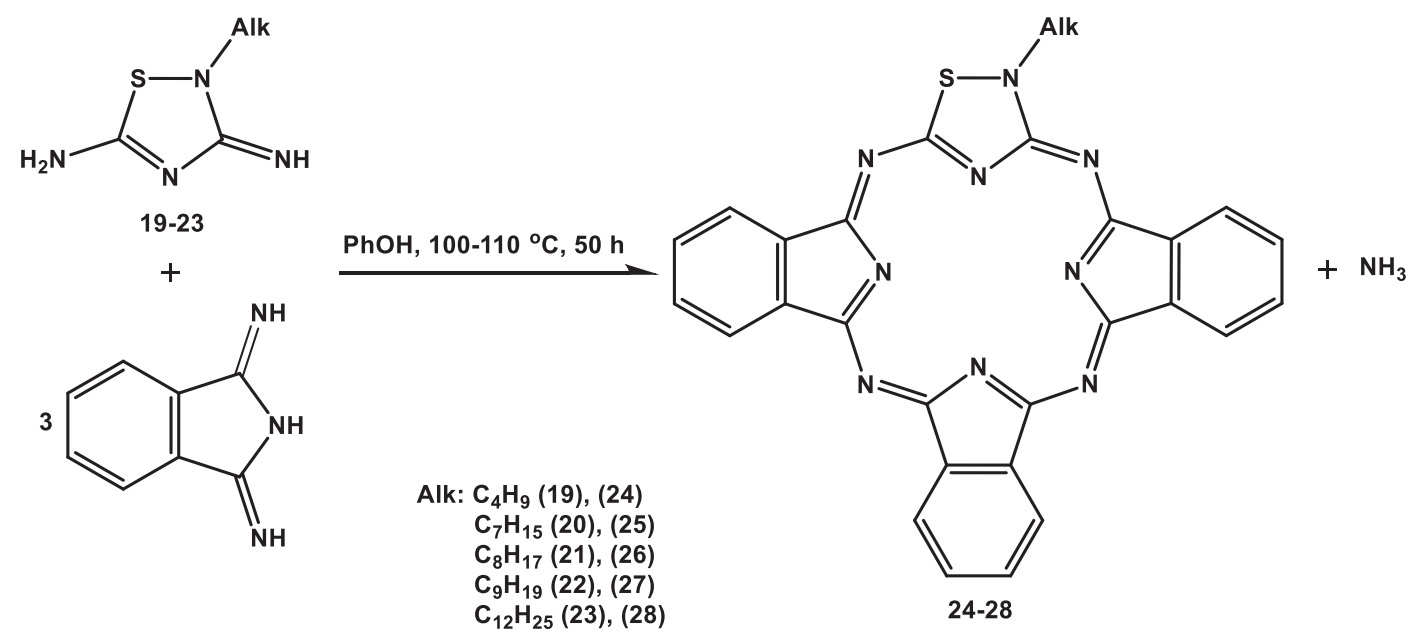

Scheme 3.

able configuration was the one in which the proton addition takes place at the intracyclic nitrogen atom of the isoindole residue located opposite the thiadiazole ring.

The unique optic properties of $\mathbf{2 4 - 2 8}$ can potentially allow these compounds to be used as therapeutic photodynamic agents. Moreover, compound $\mathbf{2 8}$ had photo emissive properties. Stokes shift value was $198 \mathrm{~nm}$. Luminescence quantum yield of $\mathbf{2 8}(\varphi=0.062)$ was higher in comparison with macroheterocyclic compounds of the ABBB type containing fragments of 3-pentyl- $(\varphi=0.013)$, 3-dodecyl$(\varphi=0.016)$ and 3-pentadecyl- $(\varphi=0.021)$ 5-amino-2-imino-1,3,4-thiadiazolines. ${ }^{[32]}$

Obtained by us compounds 5-8 and 16-18 exhibit potential antimicrobial properties as their parent molecules (1,2,4-triazole and 1,3,4-thiadiazole) are used in drugs (Diacarb, Tizanidine); besides they can demonstrate antitumor activity like metalcomplex of triazole-containing $\mathrm{ABAB}$ Mcs. ${ }^{[33]}$ Moreover, Stabilin-9 is known to be an analogues to $\mathrm{ABBB} \mathrm{Mc}$ and to increase heat and light resistance of poliamide fiber. ${ }^{[34]}$

\section{AABAAB-type Mcs with Expanded Coordination Cavity}

Unsubstituted and thus insoluble in organic solvents AABAAB-type Mc was obtained on the basis of bis(5-amino1,2,4-trizole-3-yl)methane. ${ }^{[35,36]}$ Chemical modification due to volume substitutes adding is known to increase solubility of the target compound. Therefore, we synthesized triazolecontaining AABAAB-type Mc 29 with tert-butyl substituents through the interaction of 4-tert-butylphthalonitrile and bis(5amino-1,2,4-trizole-3-yl)methane in the medium of phenol at reflux temperature. Ageing time was 40 hours (Scheme 4). ${ }^{[37]}$ The choice of the reaction medium was specified by several reasons. Firstly, the parent compound was soluble only in phenol and ethylene glycol. ${ }^{[35]}$ Secondary, phenol as a weak acid slows adverse reactions such as phthalocyanine formation. Finally, the condensation with phenol transforms phthalonitrile into more reactive form such as 5(6)-tert-butyl-1-imino3-phenoxyisoindolenin. ${ }^{[38]}$

Moreover, we were able to obtain metal complexes 30, 31 by template condensation of 4-tert-butylphthalonitrile, bis(5-amino-1,2,4-trizole-3-yl)methane and corresponding metal acetates in DMF (Scheme 5). ${ }^{[37]}$

We produced Mc 32 by condensation of bis(5amino-1,3,4-thiadizole-2-yl)ethane and 5-tert-butyldiiminoisoindoline (Scheme 6). ${ }^{[39]}$ We calculated the structure array of a model compound without tert-butyl group to simplify the optimization geometry. The setting of the initial geometry, processing and visualization of the results of calculations were performed using programs ChemCraft ${ }^{[40]}$ and Mercury 3.7. Full optimization of geometrical parameters was carried out by the density functional theory using hybrid functional B3LYP and basis set 6-31G $(\mathrm{d}, \mathrm{p}) \cdot{ }^{[4]}$ The calculation showed that the structure when sulfur atoms

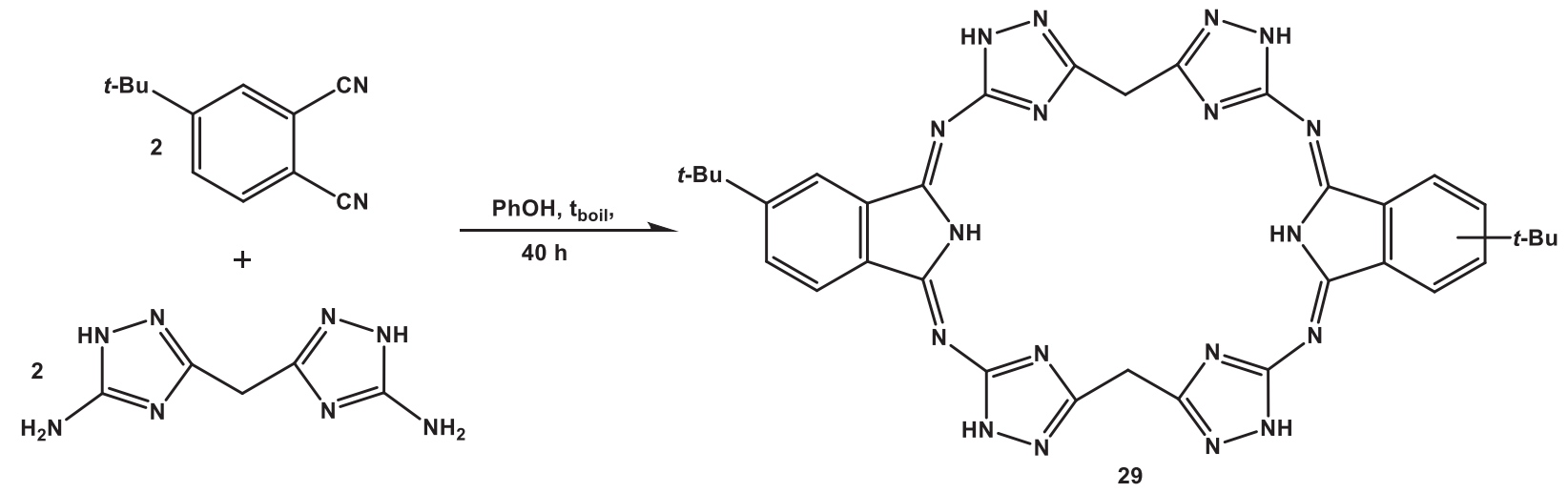

Scheme 4. 


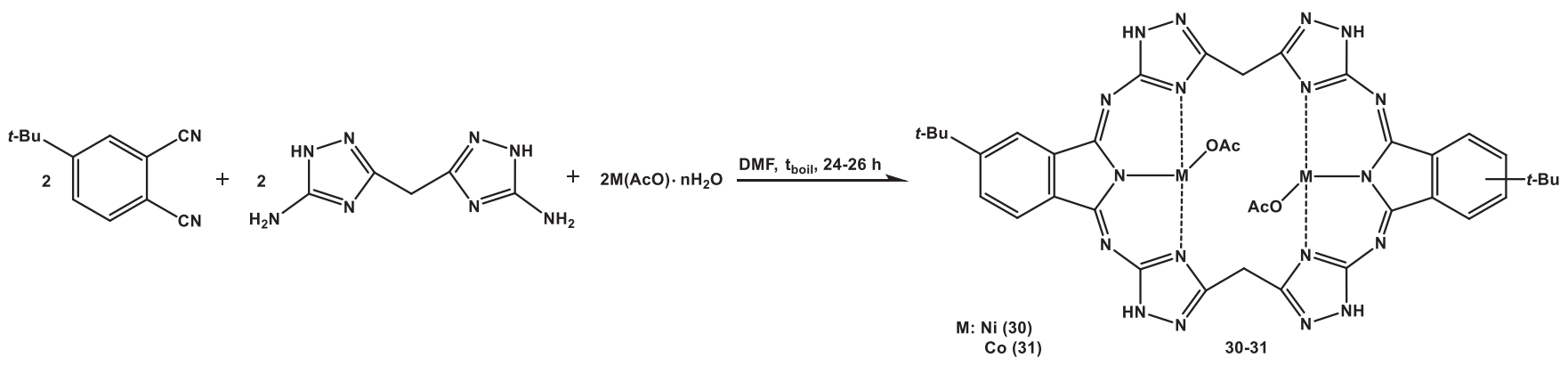

Scheme 5.

of thiadiazole were inverted outwards the macrocyclic ring had the lowest energy. These data agree well with the published data for the compounds of ABABAB-type. ${ }^{[16]}$ According to the quantum chemical data Mc 32 has nonplanar structure. Hydrogen bonds were formed between two fragments both containing the two thiadiazoles and one isoindoline moieties, their structure being nearly planar. However, the sulfur atom makes the thiadiazole cycle to deviate from the plane of the fragment. The angle between these fragments was $82^{\circ}$, while in similar compounds with bis(5-amino-1,2,4-triazole-3-yl)methane units the angle between planes was $139.9^{\circ} .^{[42]}$ This fact can be explained by the increased structural flexibility of the ethyl bridge.

As stated above, AABAAB Mcs were usually obtained from bistriazoles or bisthiadiazole. Nevertheless, we were able to perform the synthesis of AABAAB Mc 33 containing $2 N$-decyl-1,2,4-thiadiazoles through the interactions of 2N-decyl-5-amino-3-imino-1,2,4-thiadiazoline with 1,3-diiminoisoindoline in phenol (Scheme 7). ${ }^{[39]}$ We proposed that the synthesis of the target compound occurrs through the formation of intermediate products of AA and BAABtype, mass-spectrometry data have confirmed our hypothesis.

Compound $\mathbf{3 3}$ has a conjugated anti-Huckel system that explains both the absence of long-wave absorption in the UV-Vis spectrum and the presence of an intense band in the region of $456 \mathrm{~nm}$. Interesting results were obtained upon measuring the spectrum in the concentrated sulfuric acid. The intense absorption band was shifted to the long wavelength region at $24 \mathrm{~nm}$ and a new band appeared with a maximum at $745 \mathrm{~nm}$. The dilution of the sulfuric acid with water caused further bathochromic shift of the absorption band that increased over the time. In 65 days, the absorption maximum was recorded at $509 \mathrm{~nm}$. Such a change in the nature of the spectrum might depend on the stepwise protonation of the macrocyclic ligand at the nucleophilic centers. After the reprecipitation of Mc $\mathbf{3 3}$ from the solu-<smiles>CC(C)(C)c1ccc2c(c1)C(=N)NC2=N</smiles><smiles></smiles>

32

Scheme 6.

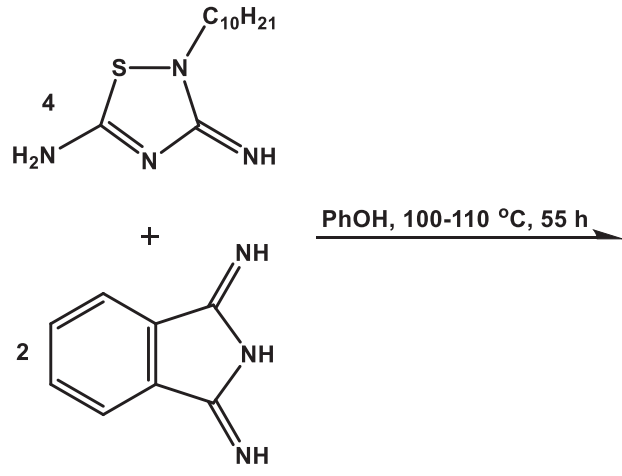

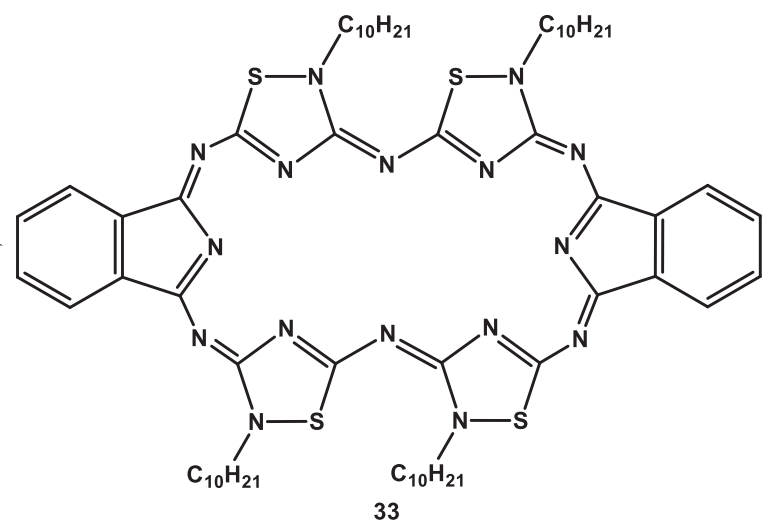

Scheme 7. 
tion of the concentrated sulfuric acid a dark suspension was formed. In this case, the intense absorption band reappeared in the region of $456 \mathrm{~nm}$ and a slight inflection remained at $745 \mathrm{~nm}$ possibly due to the presence of not completely removed proton form.

Thus, the compound $\mathbf{3 3}$ has unique stability in sulfuric acid and was kept for 65 days. It is not typical for Mcs that usually degrade within $30 \mathrm{~min}^{[6]}$

\section{Conclusions}

Thus, synthetic methods and properties of some ABBBand AABAAB-type Mcs over the last decade are surveyed.

Acknowledgements. The work was supported by the RF President's Grant MK-1396.2020.3.

\section{References}

1. Elvidge J.A., Linstead R.P. J. Chem. Soc. 1952, 20, 5008-5012.

2. Patent 2765308 USA. 1956.

3. Torre de la G., Torres T. J. Org. Chem. 1996, 61, 6446-6449.

4. Danilova E.A., Melenchuk T.V., Trukhina O.N., Zakharov A.V., Islyaikin M.K. Macroheterocycles 2010, 3, 33-37.

5. Islyaikin M.K., Danilova E.A., Yagodarova L.D., RodríguezMorgade M.S., Torres T. Org. Lett. 2001, 3, 2153-2156.

6. Islyaikin M.K., Rodríguez-Morgade M.S., Torres T. Eur. J. Org. Chem. 2002, 2460-2464.

7. Sessler J.L., Seidel D. Angew. Chem. Int. Ed. 2003, 42, 5134-5175.

8. Sessler J.L., Gale P.A., Cho W.S. In: Anion Receptor Chemistry (Stoddart J.F., Ed.), Cambridge: Royal Society of Chemistry, 2006. $430 \mathrm{p}$.

9. Yoon Z.S., Kwon J.H., Yoon M., Koh M.K., Noh S.B., Sessler J.L., Lee J.T., Seidel D., Aguilar A., Shimizu S., Suzuki M., Osuka A., Kim D. J. Am. Chem. Soc. 2006, 128, 14128-14134.

10. Borodkin V.F., Kolesnikov N.A. Khim. Geterotsikl. Soed. [Chem. Heterocycl. Compds.] 1971, 2, 194-195 (in Russ.).

11. Kolesnikov N.A., Borodkin V.F. Zh. Priklad. Spektrosk. [J. Appl. Spectrosc.] 1971, 14(6), 1124-1127 (in Russ.).

12. Kolesnikov N.A., Borodkin V.F. Izv. Vyssh. Uchebn. Zaved. Khim. Khim. Tekhnol. 1972, 15(6), 880-882 (in Russ.).

13. Islyaikin M.K., Borodkin V.F., Danilova E.A., Konovalov S.P., Panov A.A. Izv. Vyssh. Uchebn. Zaved. Khim. Khim. Tekhnol. 1990, 33(6), 18-21 (in Russ.).

14. Kobayashi N., Inagaki S., Nemykin V.N., Nonomura T. Angew. Chem. Int. Ed. 2001, 40, 2710-2712.

15. Zakharov A.V., Shlykov S.A., Danilova E.A., Krasnov A.V., Islyaikin M.K., Girichev G.V. Phys. Chem. Chem. Phys. 2009, $11,8570-8579$.

16. Trukhina O.N., Rodríguez-Morgade M.S., Wolfrum S., Caballero E., Snejko N., Danilova E.A., Gutiérrez-Puebla E., Islyaikin M.K., Guldi D.M., Torres T. J. Am. Chem. Soc. 2010, 132, 12991-12999.

17. Zakharov A.V., Shlykov S.A., Bumbina N.V., Danilova E.A., Krasnov A.V., Islyaikin M.K., Girichev G.V. Chem. Commun. 2008, 30, 3573-3575.

18. Rodríguez-Morgade M.S., Cabezón B., Esperanza S., Torres T. Chem. Eur. J. 2001, 7, 2407-2413.

19. Lindman S.V., Shklover V.E., Struchkov Yu.T., Ponomarev I.I., Siling S.A., Vinogradova S.V., Korshak V.V. Izv. Akad. Nauk SSSR Ser. Khim. 1984, 2015-2022 (in Russ.).
20. Kudrik E.V., Islyaikin M.K., Smirniv R.P. Zh. Org. Khim. 1996, 66(9), 1564-1566 (in Russ.).

21. Patent 2134270 RF, 1999.

22. Hołyńska M., Kubiak M. Acta Cryst. 2008, C64, o609-o612.

23. Danilova E.A., Melenchuk T.V., Trukhina O.N., Islyaikin M.K. Macroheterocycles 2010, 3, 68-81.

24. Tyutina M.A., Kudayarova T.V., Danilova E.A. Russ. J. Gen. Chem. 2017, 87, 1737-1741.

25. Elvidge J.A., Linstead R.P. J. Chem. Soc. 1955, 3536-3544.

26. Sanchez R., Vest G., Scott W., Engel P.S. J. Org. Chem. 1989, $54,4026-4027$.

27. Vinogradov S.V., Ulitin M.V., Lefedova O.V. Russ. J. Phys. Chem. A 1999, 73, 1741.

28. Kudayarova T.V., Danilova E.A., Koifman O.I. Russ. Chem. Bull. 2018, 12, 2262-2265.

29. Butina Yu.V., Kudayarova T.V., Danilova E.A., Semenishin N.N. Izv. Vyssh. Uchebn. Zaved. Khim. Khim. Tekhnol. 2016, 59(10), 36-40.

30. Safonova E.A., Martynov A.G., Nefedov S.E., Kirakosyan G.A., Gorbunova Y.G., Tsivadze A.Yu. Inorg. Chem. 2016, 55, 2450-2459.

31. Butina Yu.V., Danilova E.A., Kudayarova T.V., Malyasova A.S. Macroheterocycles 2018, 11, 59-66.

32. Kydayarova T.V., Danilova E.A., Islyaikin M.K., Semenishin N.N., Rusakova N.V. Russ. J. Gen. Chem. 2014, 84, $1706-1710$.

33. Islyaikin M.K., Danilova E.A., Kudrik E.V., Smirnov R.P., Budunova A.P., Kinzirskii A.S. Pharm. Chem. J. 1997, 31(8), 409-412.

34. Maslova I.P. Chemical Dopands to Polymers. Moscow: Chemisrty, 1981. p. 264 (in Russ.) [Маслова И.П. Химические добавки к полимерам. М.: Химия, 1981. с. 264.].

35. Filatov M.S., Kydayarova T.V., Danilova E.A., Islyaikin M.K. Izv. Vyssh. Uchebn. Zaved. Khim. Khim. Tekhnol. 2014, 57(7), 21-25 (in Russ.).

36. Filatov M.S. The Study of the Spatial Structure of the AAAAB-type Macroheterocyclic Compound by DFT Method. In: Quantum-Chemical Calculations: Structure and Reactivity of Organic and Inorganic Molecules. Ivanovo: ISUCT, 2011. 272 p. (in Russ.) [Филатов M.C. Изучение пространственного строения макрогетероциклического соединения ААВААВ-типа методом DFT. В кн.: Квантово-химические расчеты: структура и реакционная способность органических и неорганических молекул: сб. науч. ст. Иваново: Иван. гос. ун-т., 2011. 272 c.].

37. Kudayarova T.V., Danilova E.A., Islyaikin M.K. Izv. Vyssh. Uchebn. Zaved. Khim. Khim. Tekhnol. 2015, 58(11), 16-20 (in Russ.).

38. Siling S.A. In: Advances in Porphyrin Chemistry, Vol. 2. St. Petersburg: NII Khimii SpbGU, 1999. p. 320-329 (in Russ.) [Силинг С.А. В кн.: Успехи химии порфиринов. Т. 2. СПб.: НИИ химии СПбГУ, 1999. с. 320-329.].

39. Butina Yu.V., Danilova E.A., Kudayarova T.V. Macroheterocycles 2016, 9, 206-211.

40. Zhurko G.A. ChemCraft version 1.6, build 312, http://www. chemcraflprog.com/index.html.

41. Granovsky A.A. Firefly version 8.1.0, build number 9035 , http://classic.chem.msu.su/gran/firefly/index.html.

42. Filatov M.S. Synthesis and Properties of the Azolmacroheterocyclic Compounds with Expanded Coordination Cavity. Diss. Cand. Chem. Sci. Ivanovo: ISUCT, 2014. 140 p. (in Russ.) [Филатов M.C. Синтез и свойства азолсодержащих макрогетероциклических соединений с расширенной координационной полостью. Дисс. канд. хим. наук. Иваново: ИГХТУ, 2014. 140 с.]. 